\title{
Pemberdayaan Aset Melalui Penyuluhan Fermentasi Pakan Ternak dan Kawin Suntik Sapi dalam Peningkatan Ekonomi Warga di Dusun Jambangan
}

\author{
Ulum Fatmahanik ${ }^{1)}$ \\ ${ }^{1)}$ Institut Agama Islam Negeri Ponorogo \\ ulum.fatma@gmail.com
}

\begin{abstract}
ABSTRAK: Masyarakat di dusun Jambangan mayoritas memperoleh pendapatan yang berasal dari hasil pertanian dan peternakan. Akan tetapi para peternak masih banyak mengalami kegagalan dalam proses kawin suntik hewan ternak. Sehingga dirasa perlu melakukan penyuluhan pembuatan pakan ternak sapi dengan cara fermentasi dan juga sosialisasi terkait pelaksanaan kawin suntik sapi yang baik dan benar dengan harapan masyarakat dusun Jambangan dapat meningkatkan ekonomi dari hasil ternak sapi yang dipelihara karena dapat meminimalisir kegagalan dalam proses kawin suntik sapi. Kegiatan pengabdian masyarakat ini menggunakan pendekatan Asset Based Community Development (ABCD). Kegiatan pengabdian ini dapat berjalan dengan dan baik baik. Hal tersebut dilihat dari antusiame masyarakat yang tinggi dalam bertanya terkait problematika yang dihadapi selama memelihara sapi. Selain itu dampak lain yaitu masyarakat dapat memanfaatkan bahan-bahan yang ada di sekitar untuk membuat fermentasi pakan ternak sapi.
\end{abstract}

Kata Kunci: Pemberdayaan, Penyuluhan, Fermentasi, Kawin Suntik Sapi.

ABSTRACT: The majority of people in Jambangan village receive income from agriculture and animal husbandry. However, farmers are still experiencing a lot of failures in the process of injection of livestock. So that it is deemed necessary to conduct counseling on the production of cattle feed by means of fermentation and also socialization related to the implementation of a good and correct cow injection marriage in the hope that the Jambangan village community can improve the economy of the cattle raised because it can minimize failures in the cow injection process. This community service activity uses the Asset Based Community Development $(A B C D)$ approach. This service activity can run well and well. This can be seen from the enthusiasm of the high community in asking related problems faced while raising cattle. Besides that, another impact is that the community can utilize the materials that are around to make fermented cattle feed.

Keywords: Empowerment, Counseling, Fermentation, Cow Injecting Mating.

\section{PENDAHULUAN}

Desa Lembeyan Wetan merupakan salah satu desa di wilayah Magetan yang memiliki letak yang cukup strategis. Secara srategis Desa Lembeyan Wetan wilayah sebelah Utara berbaasan dengan Desa Pupus dan terdapat area pertanian sedangkan sebelah selatan desa berbaasan dengan hutan. Sedangkan sebelah barat berbatasan dengan Desa Tunggu. Demikian juga dengan kondisi lahan yang relatif datar dan subur sehingga sangat mendukung produktifitas hasil pertanian. Selain itu dalam pemenuhan kebutuhan sehari-hari tidak hanya bertani akan tetapi juga dengan hasil beternak. Hasil ternak di desa Jambangan ini ada yang digunakan sebagai pekerjaan sampingan, dijual maupun untuk kebutuhan sendiri. 
Sebagai daerah yang mayoritas mata pencahariaanya dengan beternak sapi, pemeliharaan ternak sebagian besar dilakukan secara tradisional. Pakan ternak umumnya hanya berupa rumput lapangan dan dedaunan tanaman keras dan bahan pakan ternak pada musim panen seperti jerami. Disamping itu peternak sapi di daerah ini belum melakukan sistem recording ternak yang dimiliki, kurangnya pengetahuan peternak dalam masalah reproduksi sapi betina dan penangan kawin suntik ternak dengan baik. Padahal beberapa faktor ini sangat penting dalam peningkatan produktivitas ternak sapi.

Akan tetapi pada kondisi tertentu pakan-pakan ternak tersebut juga sulit untuk didapatkan. Selain itu permasalahan lain yang dihadapi masyarakat adalah seringnya terjadi kegagalan dalam proses kawin suntik sapi yang menyebabkan hasil ternak sapi belum sesuai dengan harapan. Selain itu Masyarakat peternak awam masih belum mengenal fermentasi pengolahan pakan ternak yang nantinya sapi-sapi akan memiliki harga jual yang tinggi.

Selain itu Singkong (Manihot esculenta Crantz) merupakan makanan pokok ketiga setelah padi dan jagung bagi masyarakat Indonesia. Data BPS tahun 2008 menyatakan bahwa pada tahun 1995 produksi singkong Indonesia mencapai 15,44 juta ton. Produksi singkong ini meningkat menjadi 19,98 juta ton pada tahun 2007 (Wikanastri et al., 2012). Menurut Darmawan (Wikanastri et al., 2012) dari total produksi singkong akan dihasilkan lebih kurang $16 \%$ limbah kulit singkong. Jumlah limbah kulit singkong yang cukup besar ini berpotensi untuk diolah menjadi pakan ternak. Hanya saja perlu pengolahan yang tepat agar racun sianida yang terkandung dalam kulit singkong tidak meracuni ternak yang mengkonsumsinya. Salah satu proses pengolahan yang dapat menurunkan kandungan sianida dalam kulit singkong adalah proses fermentasi.

Limbah hasil pertanian dari kulit singkong yang belum dimanfaatkannya sebagai makanan ternak, melainkan mereka membuangnya atau membakarnya. Padahal limbah hasil pertanian tersebut cukup banyak dan beraneka jenisnya serta masih mengandung zat-zat makanan yang diperlukan untuk memenuhi kebutuhan ternak. Di saat panen melimpah dan limbah hasil pertanian pun cukup banyak, kulit singkong tersebut dapat diolah menjadi fermentasi dan silase kulit singkong, yang hasilnya dapat disimpan sampai berbulan-bulan sebagai simpanan yang diperlukan di saat musim kemarau di mana jumlah hijauan/rumput berkurang. Hal ini merupakan salah satu masalah yang harus dicarikan jalan keluarnya sehingga petani termotivasi atau bergairah dalam melakukan usaha ternak selain usaha tani yang berdampak meningkatkan pendapatan keluarga petani.

Salah satu jenis fermentasi yang dilakukan dalam kegiatan pengabdian ini yaitu fermentasi pakan ternak dari kulit singkong. Dalam pengabdian ini dipilih fermentasi dari kulit singkong dan kuli singkong karena kulit singkong rata-rata oleh masyarakat Jambangan sudah tidak digunakan lagi setelah singkongnya dibuat gaplek dan bahan 
inipun mudah didapatkan dengan kultur mata pencaharian masyarakat yang selain beternak juga bertani. Karena untuk pemberian makanan secara teknis dan ekonomis harus dapat memenuhi kebutuhan pokok minimal zat makanan untuk menjaga keseimbangan dan kondisi tubuh ternak sapi potong serta mudah dan murah didapat (Syaiful et al., 2018)

Berdasarkan penelitian Busairi dan Wikanastri (Wikanastri et al., 2012) diketahui bahwa proses fermentasi dapat menurunkan kandungan sianida dalam kulit singkong dari $0,024 \%$ menjadi $0,009 \%$ setelah proses fermentasi selama lima hari. Sedangkan penelitian Hersoelistyorini dan Abdullah (2010) menyatakan bahwa proses fermentasi menggunakan inokulum ragi tape dapat meningkatkan kandungan protein kulit singkong dari $10,03 \%$ menjadi $20,91 \%$ pada fermentsi hari ke lima. Dengan demikian, selain dapat menurunkan kadar sianida dalam kulit singkong, proses fermentasi juga dapat meningkatkan kandungan protein bahan.

Sedangkan kawin suntik sapi atau inseminasi buatan menurut Mozzes $\mathrm{R}$ merupakan suatu alat yang ampuh yang bisa diciptakan oleh manusia untuk meningkatkan jumlah dan produksi ternak secara kuantitatif dan kualitatif. Oleh karena itu untuk mengatasi permasalahan yang dialami oleh peternak di dusun Jambangan Desa Lembeyan Wetan perlu diadakan kegiatan pengabdiayan tentang penyuluhan fermentasi pakan ternak dan kawin suntik sapi dengan harapan dari kegiatan ini masyarakat Jambangan dapat meminimalisir kegagalan kawin sutik sapi serta mempunyai alternatif pakan ternak yang sudah difermentasi.

\section{PERMASALAHAN}

Berdasarkan pendahuluan diatas, permasalahan yang dihadapi masyarakat peternak di dusun Jambangan Desa Lembeyan Wetan adalah Seringnya terjadi kegagalan dalam proses kawin suntik sapi yang menyebabkan hasil ternak sapi belum sesuai dengan harapan, serta Masyarakat peternak awam masih belum mengenal fermentasi pengolahan pakan ternak yang nantinya sapi-sapi akan memiliki harga jual yang tinggi.

\section{METODE PELAKSANAAN}

Pengabdian kepada masyarakat ini menggunakan pendekatan Asset Based Community Development (ABCD) dengan prinsip pengembangan masyarakat setengah terisis lebih berarti, semua punya potensi, partisipasi, kemitraan, penyimpangan positif, berasal dari dalam masyarakat dan mengarah pada sumber energi. proses apprecitive inquiry atau model 4D yang terdiri dari 4 tahap yaitu (2019):

1) Discovery adalah proses pencarian yang mendalam tentang hal-hal poitif, hal-hal terbaik yang pernah dicapai, dan pengalaman-pengalaman keberhasilan dimasa lalu proses ini dilakukan dengan wawancara apresiatif. 
2) Dream merupakan tahap dari informasi sebelumnya masyarakat dampingan kemudian mulai membayangkan masa depan yang diharapkan. Pada tahap ini setiap orang mengeksplorasi harapan dan impian mereka baik unuk diri mereka sendiri maupun untuk organisasi.

3) Design pada tahap ini mulai merumuskan srategi proses dan sistem, membuat keputusan dan mengembangkan kolaborasi yang mendukung terwujudnya perubahan yang diharapkan. Pada tahap ini semua hal positif dimasa lalu ditransformasikan menjadi kekuaan untuk mewujudkan perubahan yang diharapkan.

4) Destiny yaitu tahap dimana setiap masyarakat pendamping dalam organisasi mengimplementasikan berbagai hal yang sudah dirumuskan pada tahap design yaitu pelaksanaan penyuluhan dan pelatihan pembuaan fermentasi pakan ternak dan kawin suntik sapi.

\section{PELAKSANAAN}

Adapun pelaksanaan dalam kegiatan pengabdian ini yang melalui 4 tahap diuraikan sebagai berikut. Pertama tahap discovery pada kegiatan ini dilakukan proses pencarian yang mendalam tentang hal-hal poitif, hal-hal terbaik yang pernah dicapai yang dimiliki oleh masyarakat Jambangan. Adapun berdasarkan hasil wawancara apresiatif warga Jambangan ternyata memiliki berbagai ase diberbagai bidang diantaranya aset personal berupa keahlian dalam bidang kewirausahaan, seperti keahlian bertani jagung, padi dan kacang tanah, ketrampilan pengrajin tas dari tali kur, sentral usaha ayam panggang, usaha kripik tempe dan usaha krupuk bawang, keahlian dalam memelihara sapi, kambing, ayam, beternak ayam petelur dan bebek.

Aset sosial berupa organisasi yang terdiri dari kelompok remaja dusun, PKK, kelompok ani dan kelompok hadroh. Aset alam berupa terdapatnya lahan pertanian yang digunakan sebagai mata pencaharian utama, sungai yang digunakan untuk mengairi sawah dan peernakan juga menjadi salah satu asset alam yang dimilliki dususn AJmbangan sebab sebagian besar penduduk dusun memiliki hewan ternak yang dibudidayakan sebagai sumber penghasilan jangka panjang.

Aset fisik yang dimiliki desa Jambangan berupa traktor untuk membajak sawah,selain itu juga milliki alat untuk memanen padi. Asset fisik lain dalam bidang kewirausahaan berupa alat pemotong krupuk, oven unuk menggorneng kacang bagi pengusaha kacang goring dan penjahit bagi pengusaha tas rajut. Sedangkan aset spiritual Dusun Jambangan mempunyai pengetahuan agama yang sangat minim namun kegiatan keagamaan tetap dapat terlaksana dengan baik. Dari berbagai aset yang dimiliki oleh dusun Pada tahap dream masyarakat dampingan diajak untuk membayangkan masa depan yang diharapkan. Adapun mimpi dari masyarakat dusun Jambangan yaitu menjadi desa yang produktif dan mandiri salah satunya dengan meningkatkan hasil peranian, kewirausahaan dan peternakan. kegiatan keagamaan yang dapat kembali 
hidup setelah beberapa lama meredup, serta ingin adanya dukungan dan motivasi serta adanya pemerintahan yang dapat mendukung dan menggerakkan masyarakat dampingan.

Pada tahap design mulai merumuskan srategi proses dan sistem, membuat keputusan dan mengembangkan kolaborasi yang mendukung terwujudnya perubahan yang diharapkan. Pada tahap ini kegiatan pengabdian berfokus pada peningkatan hasil peternakan melalui kegiatan pengabdian di dusun Jambangan setelah dilakukan prioritas maka dalam meningkatkan ekonomi masyarakat dipilihlah aset peternakan yaitu dengan melaksanakan kegatan penyuluhan fermentasi pakan ternak dan kawin suntik agar dapat meningkatkan ekonmi masyarakat Jambangan.

Terakhir tahap destiny yaitu tahap dimana masyarakat dampingan melaksanakan apa yang dirmuskan dalam tahap design. Adapun detail pelaksanaannya yaitu sebagai berikut kegiatan penyuluhan diawali dengan pembukaan,pembacaan ayat suci Alquran dan dialnjutkan penyuluhan oelh bapak kepala dusun Jambangan lalu dilanjutkan dengan pemateri DR. H. Sri Nardi. Penyuluhan dan pelatihan ini dilakukan di rumah alm. Bpk Mochadi yang diikuti bapak-bapak warga dusun Jambangan yang berjumlah 40 orang. Antusias warga yang datang sangat baik dengan banyak pertanyaan yang diajukan kepada pemateri, sehingga mnjadi lebih hidup dan menyenangkan. Hal ini dapat dilihat dari Persepsi masyarakat dampingan terhadap materi, metode dan media penyuluhan.

Proses kawin suntik atau bisa di sebut iseminasi buatan adalah suatu cara atau teknik untuk memasukkan mani (sperma atau semen) yang telah dicairkan dan telah diproses terlebih dahulu yang berasal dari ternak jantan ke saluran alat kelamin betina dengan menggunakan metode dan alat khusus yang disebut Inseminaton gun. Cara penampungan semen dapat dilakukan 1-3 x /minggu harus terampil dalam menyiapkan alat penampung (vagina buatan) dan terampil dalam menampung semen. Hanya kualitas baik yang dapat diproses lebih lanjut. Sedangkan waktu melakukan iseminasi buatan, ternak atau sapi betina harus dalam keadaan birahi, karena pada saat itu ilang leher Rahim (servis) pada posisi yang terbuka. Kemungkinan terjadinya konsepsi (kebuntingan) bila diinseminasi pada periode-periode tertentu.

Dalam pembuatan fermentasi bahan dan alat yang digunakan dalam pembuatan fermentasi pakan ternak sapi Silase kulit singkong dilakukan dalam beberapa tahapan. Tahapan tersebut dilakukan mulai dari bahan sampai dengan hasil produksi. Tahapan tersebut adalah sebagai berikut.
Bahan Utama :
Alat :
a. Jerami
a. Drum
b. Ampas Singkong
b. Plastik
c. Kulit singkong
c. Parang
d. Tetes $250 \mathrm{ml}$
e. Starbio/EM4 100g 
f. Garam $250 \mathrm{~g}$

g. Air bersih 1 liter

Cara Pembuatan :

a. Cincang kulit singkong dan jerami sampai halus/lembut

b. Hamparkan ampas singkong, kulit singkong dan jerami

c. Campur tetes, starbio/EM4, garam dan air bersih sampai rata

d. Siramkan diatas hamparan ampas singkong, kulit singkong, dan jerami sambil di bolak-balik sampai merata.

e. Masukan semua bahan yang sudah tercampur ke dalam drum penyimpanan

f. Tutup drum dengan rapat

g. Hasil fermentasi dapat di buka atau digunakan setelah 2 minggu penyimpanan.

Alternatif Penyimpanan :

a. Alternatif penyimpanan 1

Masukkan campuran tersebut dalam tong kemudian diinjak-injak sampai padat sehingga tidak ada rongga udara/bisa dipress untuk menghilangkan udara, kemudian tutup rapat.

b. Alternatif penyimpanan 2

Masukkan ampas singkong, kulit singkong dan jerami dalam wadah plastic, injak-injak sampai padat sehingga tidak ada rongga udara didalamnya kemudian ikat sampai kencang.

\section{Cara Penggunaan :}

a. Silase bisa diberikan ke ternak setelah 15 hari.

b. Tanda silase jadi :

1) Warna ampas singkong, kulit singkong dan jerami masih terlihat hijau

2) Bau asam dan wangi

3) Rasa manis dan asam

4) Tekstur ampas singkong, kulit singkong dan jerami masih jelas

5) Tidak berjamur

6) Tidak menggumpal

7) Tidak berlendir

c. Silase bisa bertahan selama 2 bulan.

\section{HASIL DAN LUARAN}

Adapun hasil persepsi masyarakat dampingan terhadap materi,metode dan media penyuluhan fermentasi pakan ternak sapi kulit singkong disajikan dalam Tabel 1. 
Tabel 1. Persepsi Masyarakat Dampingan Terhadap Materi, Metode dan Media Penyuluhan Fermentasi Pakan Ternak Sapi

\begin{tabular}{|c|c|c|c|}
\hline Uraian & Kriteria & $\begin{array}{c}\text { Jumlah } \\
\text { Responden } \\
\text { (orang) }\end{array}$ & $\begin{array}{c}\text { Persentase } \\
(\%)\end{array}$ \\
\hline \multirow{4}{*}{$\begin{array}{l}\text { Kesesuaian materi dengan } \\
\text { kebutuhan }\end{array}$} & Tidak Sesuai & 0 & 0 \\
\hline & Kurang Sesuai & 2 & 5 \\
\hline & Sesuai & 5 & 12.5 \\
\hline & Sangat Sesuai & 33 & 82.5 \\
\hline \multirow[t]{4}{*}{ Aktualitas materi } & Tidak Aktual & 12 & 30 \\
\hline & Kurang Aktual & 10 & 25 \\
\hline & Aktual & 12 & 30 \\
\hline & Sangat Aktual & 4 & 10 \\
\hline \multirow{4}{*}{$\begin{array}{l}\text { Kemudahan dalam } \\
\text { memahami materi }\end{array}$} & Tidak Mudah & 2 & 5 \\
\hline & Kurang Mudah & 7 & 17.5 \\
\hline & Mudah & 25 & 62.5 \\
\hline & Sangat Mudah & 6 & 15 \\
\hline \multirow{4}{*}{$\begin{array}{l}\text { Kesukaan terhadap metode } \\
\text { dan media penyuluhan yang } \\
\text { digunakan }\end{array}$} & Tidak Suka & 0 & 0 \\
\hline & Kurang Suka & 2 & 5 \\
\hline & Suka & 30 & 75 \\
\hline & Sangat Suka & 8 & 20 \\
\hline \multirow{4}{*}{$\begin{array}{l}\text { Kesesuaian metode dengan } \\
\text { materi }\end{array}$} & Tidak Sesuai & 5 & 12.5 \\
\hline & Kurang Sesuai & 8 & 20 \\
\hline & Sesuai & 19 & 47.5 \\
\hline & Sangat Sesuai & 8 & 20 \\
\hline \multirow{4}{*}{$\begin{array}{l}\text { Kesesuaian media } \\
\text { materi }\end{array}$} & Tidak Sesuai & 5 & 12.5 \\
\hline & Kurang Sesuai & 7 & 17.5 \\
\hline & Sesuai & 23 & 57.5 \\
\hline & Sangat Sesuai & 5 & 12.5 \\
\hline
\end{tabular}

Dari tabel 1 atas dapat dilihat bahwa respon atau persepsi masyarakat dampingan dalam hal kesesuaian materi dengan kebutuhan yaitu dalam kategori sangat sesuai dengan tingakatan persentase $82,9 \%$. Sedangkan aktualitas materi atau up to date materi berada pada kategori akual yaiu dengan tingkata 30\%. Adapun respon atau persepsi masyarakat dampingan dalam hal kemudahan dalam memahami materi yaitu sebagian besar masyarakat dengan persentase $62,5 \%$ menyatakan mudah memahami. Sedangkan persepsi masyarakat dampingan terhadap Kesukaan terhadap metode dan media penyuluhan yang digunakan $75 \%$ menyatakan sesuai.

Persepsi terhadap kesesuaian metode dengan materi penyuluhan mempunyai tingkat kesesuaian $47,5 \%$ sedangkan kesesuaian media dengan materi penyuluhan respon dari masayarakat dampingan mempunyai ktingkat kesesuaian 57.5\%. dalam prosesnya penyuluhan penyuluh lebih menekankan kepada praktek pembuatan 
fermentasi pakan ternak sapi karena Pakan merupakan materi yang banyak diberikan oleh penyuluh, tidak terlepas dari permasalahan pakan yang paling sering dihadapi oleh peternak dalam pengembangan sapi potong. Hal ini sesuai dengan pernyataan Budiman (Abdullah \& Ibrahim, 2014) menyatakan bahwa pengembangan pakan memiliki permasalahan-permasalahan, antara lain, a) kebutuhan bahan baku pakan tidak seluruhnya dipenuhi dari lokal sehingga masih mengandalkan impor, b) bahan baku pakan lokal belum dimanfaatkan secara optimal, c) ketersediaan pakan lokal tidak kontinyu dan kurang berkualitas, d) penggunaan tanaman legum sebagai sumber pakan belum optimal, e) pemanfaatan lahan tidur dan lahan integrasi masih rendah, f) penerapan teknologi pakan masih rendah, g) produksi pakan nasional tidak pasti akibat akurasi data yang kurang tepat, serta $\mathrm{h}$ ) penelitian dan aplikasinya tidak sejalan.

\section{KESIMPULAN}

Kegiatan pengabdian kepada masyarakat yang dilakukan di Dusun Jambangan Desa lembeyan Wetan berupa penyuluhan fermentasi pakan ternak dan kawin suntik sapi dengan menggunakan pendekatan Asset Based Community Development dapat berjalan dengan baik hal tersebut terlihat selama pelaksanaan dari antusiame masyarakat yang tinggi dalam bertanya terkait problematika yang dihadapi selama memelihara sapi. Selain itu dampak lain yaitu masyarakat dapat memanfaatkan bahan-bahan yang ada di sekitar untuk membuat fermentasi pakan ternak sapi.

\section{DAFTAR PUSTAKA}

Abdullah, A., \& Ibrahim, H. (2014). Persepsi Peternak terhadap Kinerja Penyuluh dalam Pengembangan Teknologi Pengolahan Jerami Padi dan Limbah Ternak Sapi Potong. Jurnal Ilmu Dan Teknologi Peternakan Tropis, 1(1), 99-107.

Buku Pedoman KPM ABCD (Kuliah Pengabdian Masyaraka Asse Based CommunityDriven Development). (2019). Lembaga Penelitian dan Pengabdian Kepada Masyarakat (LPPM) IAIN Ponorogo.

Kawin Suntik Pada Ternak Sapi. (n.d.). Retrieved September 30, 2019, from https://www.peternakankita.com/kawin-suntik-pada-ternak-sapi/

Syaiful, F. L., Dinata, U. G. S., \& Ferido, F. (2018). Pemberdayaan masyarakat Nagari Sontang Kabupaten Pasaman melalui inovasi budidaya sapi potong dan inovasi pakan alternatif yang ramah lingkungan. Buletin Ilmiah Nagari Membangun, 1(3), 21-31.

Wikanastri, H., Suyanto, A., \& Utama, C. S. (2012). Aplikasi Proses Fermentasi Kulit Singkong Menggunakan Starter Asal Limbah Kubis Dan Sawi Pada Pembuatan Pakan Ternak Berpotensi Probiotik. PROSIDING SEMINAR NASIONAL \& INTERNASIONAL, 1 . 